\title{
Praktek Administrasi Badan Pendapatan, Pengelolaan Keuangan Dan Aset Daerah Dalam Pengenaan Pajak Di Kabupaten Magelang
}

\author{
Rinaldy Prabuningtyas \\ Magister Kenotariatan Fakultas Hukum Universitas Islam Indonesia Yogyakarta Indonesia \\ Jln. Cik Di Tiro No. 1 Yogyakarta Indonesia \\ prabuningtyasrinaldy93@gmail.com
}

Key Word:
Fee for the
Acquisition of Rights
on Building Land
(BPHTB), Regional
Revenue, Financial
and Asset
Management Agency
(BPPKAD),
validation

Abstract

This study analyzes the administrative practice of BPPKAD in the imposition of BPHTB taxes in Magelang Regency. There are 2 (two) problem formulations, namely first, what is the legal basis applied by BPPKAD in carrying out BPHTB tax collection in Magelang Regency? Second, what is the basis for the authority of the Magelang Regency BPPKAD validator to change the transaction price, especially in the transfer of sale and purchase rights. This research is a sociological juridical research using a statutory and conceptual approach. The results of this study concluded, first, the legal basis used by BPPKAD is the Regent's Decree Number 180.182/327/kep/31/2015 on the Land Value Index, but in reality the tax imposition is based on the Land Value Zone system used by the Ministry. $A T R / B P N$ without binding regulations to use the Land Value Zone system. Second, $B P P K A D$ does not have the authority to determine the price of land parcels that are the object of the transfer of sale and purchase rights by the parties, its authority is limited to validating the SSPD-BPHTB. The law only regulates the authority to collect BPHTB) which is the authority of the regional government, as regulated in Law No. 28 of 2009 on Regional Taxes and Levies

\begin{abstract}
Abstrak
Penelitian ini menganalisis praktek administrasi BPPKAD dalam Pengenaan Pajak BPHTB di Kabupaten Magelang. Terdapat 2 (dua) rumusan masalah, yakni, pertama, apa landasan hukum yang diterapkan oleh BPPKAD dalam melaksanakan penarikan pajak BPHTB di Kabupaten Magelang? Kedua, apa dasar wewenang validator BPPKAD Kabupaten Magelang mengubah harga transaksi khususnya dalam peralihan hak jual beli. Penelitian ini merupakan penelitian yuridis sosiologis dengan menggunakan pendekatan perundangundangan dan konseptual. Hasil penelitian ini menyimpulkan, pertama, landasan hukum yang digunakan oleh BPPKAD adalah Surat Keputusan Bupati Nomor 180.182/327/kep/31/2015 tentang Indeks Nilai Tanah, namun kenyataannya yang dipergunakan untuk pengenaan pajak berdasarkan sistem Zona Nilai Tanah yang dipergunakan oleh Kementerian ATR/BPN tanpa adanya peraturan yang mengikat untuk menggunakan sistem Zona Nilai Tanah tersebut. Kedua, BPPKAD tidak memiliki kewenangan untuk menentukan harga bidang tanah yang menjadi obyek peralihan hak jual beli oleh para pihak, kewenangannya sebatas memvalidasi SSPD-BPHTB. Undang-undang hanya mengatur kewenangan pemungutan $\mathrm{BPHTB}$ ) yang merupakan kewenangan pemerintah daerah, sebagaimana diatur dalam Undang-Undang No. 28 tahun 2009 tentang Pajak Daerah dan Retribusi Daerah
\end{abstract}

\section{Pendahuluan}

Pelaksanaan Bea Perolehan Hak Atas Tanah dan Bangunan (BPHTB) mengenai pengenaan pajak atas peralihan hak di Kabupaten Magelang dimulai sejak 01 Januari 
2011. BPHTB kewenangan pemungutannya dialihkan oleh Pemerintah Pusat ke Pemerintah Daerah berdasarkan Undang-Undang Nomor 28 Tahun 2009 tentang Pajak Daerah dan Retribusi Daerah. Badan Pendapatan, Pengelolaan Keuangan, dan Aset Daerah (BPPKAD) Kabupaten Magelang mempunyai tugas membantu Bupati Magelang menyelenggarakan fungsi penunjang urusan pemerintahan dibidang keuangan.

Penulis mendapatkan suatu permasalahan dalam pelaksanaan pengenaan BPHTB di Kabupaten Magelang. Petugas BPPKAD memiliki target tersendiri agar para wajib pajak dapat membayarkan pajaknya semaksimal mungkin atau setidaknya melebihi target Badan Pemungutan Pajak baik pusat maupun daerah. Penggunaan nilai transaksi sesuai dengan harga pasar cenderung jauh lebih tinggi dari Nilai Jual Obyek Pajak Bumi dan Bangungan (NJOP PBB), sehingga petugas pajak dalam menentukan nilai transaksi yang sebenarnya tidaklah mudah.

Petugas BPPKAD harus mencari data dan keterangan ataupun informasi dari berbagai pihak dalam melakukan penelitian atas kebenaran nilai transaksi yang dipakai wajib pajak untuk menghitung BPHTB, yang sebenarnya tidak mudah untuk memperoleh nilai yang pasti dan menjamin kebenaran. Bahkan tidak menutup kemungkinan nilai transaksi yang ditentukan oleh petugas pajak ini justru tidak sesuai dengan kenyataan yang sebenarnya. Hal inilah yang menjadi masalah karena tidak adanya kepastian mengenai nilai transaksi. Namun, sebenarnya pihak BPPKAD telah memiliki standarisasi dari setiap daerah mengenai harga-harga objek tanah yang selanjutnya di namakan INT (Indeks Nilai Tanah). Namun, dengan adanya INT ini dalam pelaksanaanya justru menuai banyak pro dan kontra mengingat nilai standarisasi BPPKAD berbeda dengan nilai pasaran masyarakat. ${ }^{1}$

Permasalahan yang menyangkut kinerja Pejabat Pembuat Akta Tanah (PPAT) terdapat dalam nilai transaksi baik yang diajukan oleh wajib pajak yang dimuat dalam akta PPAT sebagaimana menjadi dasar perhitungan BPHTB dengan nilai transaksi, atau yang diajukan oleh PPAT selaku kuasa dari pemohon peralihan hak jual-beli. Tim BPPKAD sejatinya memang bermitra dengan PPAT namun karena bertitik tumpu melihat harga tanah dan objek pajak, sehingga dapat menimbulkan ketidakpastian. Berdasarkan hal tersebut, maka perlu dikaji secara mendalam mengenai nilai yang tepat dan pasti sebagai dasar penghitungan pengenaan nilai transaksi yang menyangkut BPHTB yang harus dibayar oleh masyarakat yang melakukan peralihan hak atas tanah.

Permasalan lain yang penulis temukan dalam dunia kerja perpajakan BPHTB di kantor BPPKAD setempat yaitu dimana harga yang tertera asli dari pembeli dengan kesaksian dari wajib pajak sendiri masih diragukan, dimana nilai transaksi nominal dalam akta kurang dipercaya dan memberikan saran kepada wajib pajak untuk meminta surat pernyataan keaslian transaksi kepada kantor kelurahan setempat. Dalam hal ini pun muncul permasalahan apabila harga yang disampaikan oleh wajib pajak memang harga sebenarnya dan harga tidak disetujui oleh pihak BPPKAD. Hal ini menjadi rancu bagi masyarakat mengenai apakah masyarakat (wajib pajak) harus menyesuaikan dengan

1 Ady Supratno, 'Pengaruh Perubahan Zona Nilai Tanah Dan Nilai Jual Objek Pajak Bangunan Terhadap Penerimaan Pajak Bumi Dan Bangunan Perdesaan Dan Perkotaan Kabupaten Sambas", Artikel Ilmiah, Program Studi Magister Ilmu Ekonomi Fakultas Ekonomi Dan Bisnis Universitas Tanjungpura, 2018, hlm. 2. 
harga yang tertera atau wajib pajak dapat tetap mempertahankan harga sebenarnya mengenai objek yang dijadikannya objek jual beli tersebut.

Berangkat dari permasalahan tersebut, tidak menutup kemungkinan PPAT dalam prakteknya juga melakukan cara agar harga yang dilaporkan oleh para klien kepada PPAT menjadi tidaklah orisinal lagi. Tidak sedikit PPAT dalam prakteknya tidak mencantumkan harga sebenarnya objek tanah dari peralihan hak atas jual beli. Terlebih lagi, dimungkinkan terdapat nilai yang berbeda dengan yang dikeluarkan BPPKAD yang berpatok pada INT sehingga tidak sama antara hitam diatas putih dan dengan kenyataan. Penyebab lain adalah dilakukannya malapraktek oleh Notaris/PPAT demi kerjasama bisnis dengan klien, maka meski harga riil sudah rendah namun Notaris/PPAT tetap menerapkan pengaplikasian nilai transaksi yang rendah saat dicantumkan dalam akta otentik Notaris/PPAT. Hal tersebut yang membuat tim dari BPPKAD menjadi enggan percaya dengan harga yang tertulis secara hitam diatas putih dalam sebuah akta jual beli yang objeknya tanah (atau dengan bangunan diatasnya). Berdasarkan uraian diatas penulis tertarik untuk meneliti lebih lanjut tentang "Praktek Administrasi Badan Pendapatan, Pengelolaan Keuangan Dan Aset Daerah Dalam Pengenaan Pajak BPHTB Di Kabupaten Magelang".

\section{Rumusan Masalah}

Terdapat dua rumusan masalah, yakni, pertama, apa landasan hukum yang diterapkan oleh Badan Pendapatan, Pengelolaan Keuangan dan Aset Daerah dalam melaksanakan penarikan pajak BPHTB di Kabupaten Magelang? Kedua, apa dasar wewenang validator Badan Pendapatan, Pengelolaan Keuangan dan Aset Daerah Kabupaten Magelang mengubah harga transaksi khususnya dalam peralihan hak jual beli?

\section{Tujuan Penelitian}

Terdapat dua tujuan dalam penelitian ini, pertama, untuk menganalis landasan hukum yang diterapkan oleh Badan Pendapatan, Pengelolaan Keuangan dan Aset Daerah dalam melaksanakan penarikan pajak BPHTB di Kabupaten Magelang. Kedua, untuk menganalisis dasar wewenang validator Badan Pendapatan, Pengelolaan Keuangan dan Aset Daerah Kabupaten Magelang mengubah harga transaksi khususnya dalam peralihan hak jual beli.

\section{Metode Penelitian}

Penelitian ini merupakan penelitian yuridis sosiologis dengan mengkaji hukum dalam pelaksanaan (law in action)2, dalam hal ini untuk mengkaji mengenai Praktek Administrasi Badan Pendapatan, Pengelolaan Keuangan dan Aset Daerah (BPPKAD) Dalam Pengenaan Pajak BPHTB di Kabupaten Magelang. Penelitian menggunakan pendekatan perundang-undangan dan konseptual. Penelitian ini menggunakan data

\footnotetext{
${ }^{2}$ Ronny Hanitijo Soemitro, Metode Penelitian Ilmu Hukum, Ghalia Indonesia, Jakarta, 1990, hlm. 35.
} 
primer, sekunder, dan tersier. Pada penelitian pengumpulan data dilakukan dengan cara studi dokumen/pustaka/literatur ${ }^{3}$, sedangkan data dianalisis secara kualitatif yaitu, metode analisis data dengan cara mengelompokkan dan menseleksi data yang diperoleh dari penelitian menurut kualitas dan kebenarannya, kemudian dihubungkan dengan teori-teori dari studi kepustakaan sehingga diperoleh jawaban atas permasalahan dalam penelitian ini. ${ }^{4}$

\section{Hasil Penelitian dan Pembahasan}

\section{Landasan Hukum yang Diterapkan oleh BPPKAD dalam Melaksanakan Penarikan Pajak BPHTB di Kabupaten Magelang}

BPPKAD dalam pelaksanaan sistem administrasinya, menerapkan INT per daerah yang diberikan berbagai macam tingkatan indeks yang berbeda. Hal ini karena, setiap daerah atau dusun mengikuti tafsiran per-blok yang telah ditandai oleh Kantor BPPKAD. Penandaan blok ini tentunya memiliki harga Indeks Nilai Pasar Tanah yang berbeda disetiap bloknya dengan patokan harga pasar pada setiap meternya yang ditafsirkan berdasarkan blok pada Nilai Objek Pajak (NOP) Pajak Bumi dan Bangunan (SPPT-PBB) masing-masing objek tanah di suatu tempat dalam ruang lingkup kabupaten.

Menyikapi hal tersebut ada hal lain yang tidak kalah menarik mengenai seputar data-data yang tertera dalam Nilai Objek Pajak (NOP) Pajak Bumi dan Bangunan (SPPTPBB) tersebut, contohnya yaitu Nilai Jual Objek Pajak (NJOP). Penulis dapat memberikan pemahaman menarik dalam penentuan INT yang sebagaimana termuat dalam Surat Keputusan Bupati Nomor 180.182/327/kep/31/2015 tentang INT di Kabupaten Magelang. Penentuan INT dalam surat keputusan tersebut hampir tidak sama nilai nominal datanya dengan Nilai Nilai Jual Objek Pajak (NJOP) permeter itu sendiri.

Oleh karenanya, penulis menemukan adanya perbedaan data antara INT permeter dengan NJOP permeter. Seharusnya dalam penerapan ini, pemerintah daerah dapat lebih mencermati perbedaan perbedaan nilai nominal ini, karena NJOP per meter adalah gambaran data secara valid yang diterima oleh masyarakat secara luas yang sebagaimana dijadikan patokan masyarakat dalam patokan pengambilan harga objek tanah khususnya pada masyarakat pemilik tanah tersebut. Artinya, NJOP digunakan pembeli atau penjual objek tanah sebagai patokan untuk menentukan harga terendah sebuah objek tanah. Pada kenyataannya, harga yang di gunakan adalah harga permeter yang termuat dalam Surat Keputusan Bupati Nomor 180.182/327/kep/31/2015 yang hanya masyarakat tertentu yang dapat mengetahui SK ini, seperti PPAT dan PPATS yang terbatas pada satu kabupaten ruang lingkup dan tidak sampai merangkup hingga kota madya.

Hasil nilai dari NJOP dengan dikalikan luas objek tanah dan setelahnya disebut dengan Nilai Jual Objek Pajak Pajak Bumi dan Bangunan (NJOP PBB). Nilai Jual Objek Pajak (PBB) ini dibandingkan dengan harga transaksi/nilai pasar, apabila NJOP PBB lebih besar dari harga transaksi maka Nilai Jual Objek Pajak (PBB) yang akan dijadikan sebagai Nilai Perolehan Objek Pajak (NPOP) atau yang akan dijadikan patokan harga

3 Maria S.W. Sumardjono, Pedoman Pembuatan Usulan Penelitian, PT. Grameda Pustaka Utama, Jakarta, 1997, hlm. 32

${ }^{4}$ Abdulkadir Muhammad, Hukum dan Penelitian Hukum, Citra Aditya Bakti, Bandung, 2004, hlm. 51. 
utama, sedangkan apabila harga transaksi lebih tinggi dari Nilai Jual Objek Pajak (PBB) maka harga transaksi yang akan dijadikan sebagai patokan dalam penentuan Nilai Perolehan Objek Pajak (NPOP). Hal ini merupakan dasar hukum perhitungan Bea Perolehan Hak Atas Tanah dan Bangunan (BPHTB), yang perhitungannya jarang ditemui Nilai transaksi dibawah Nilai Nilai Perolehan Objek Pajak (NPOP) di Kabupaten Magelang.

Dalam praktiknya, landasan hukum yang diterapkan oleh BPPKAD dalam melaksanakan penarikan pajak BPHTB di Kabupaten Magelang menurut beberapa responden yang berhasil penulis wawancarai diantaranya adalah Suprayitno dan Alam Purnomo Aji, mewakili BPPKAD adalah, pertama, menurut Bapak Alam Purnomo Aji ${ }^{5}$ landasan hukum penarikan Bea Perolehan Hak Atas Tanah dan Bangunan (BPHTB) adalah sebagai berikut:

1. Undang-Undang Nomor 28 Tahun 2009 tentang Pajak Daerah dan Retibusi Daerah,

2. Peraturan Bupati No. 64 Tahun 20016 tentang Kedudukan, Susunan Organisasi, Tugas dan Fungsi, Serta Tata Kerja Badan Pendapatan, Pengelolaan Keuangan dan Aset Daerah,

3. Peraturan Daerah Kabupaten Magelang Nomor 13 Tahun 2010 tentang Pajak Daerah, Peraturan Daerah Kabupaten Magelang Nomor 10 Tahun 2012 tentang Pajak Bumi dan Bangunan Perdesaan dan Perkotaaan;

4. Peraturan Bupati Magelang Nomor 51 Tahun 2010 tentang Prosedur Pemungutan Bea Perolehan Hak Atas Tanah dan Bangunan;

5. Peraturan Bupati Magelang Nomor 52 Tahun 2010 tentang Tata Cara Pemberian dan Pemanfaatan Insenif Pemungutan Pajak Daerah;

6. Peraturan Bupati Magelang Nomor 4 Tahun 2012 tentang Petunjuk Pelaksanaan Pemungutan Pajak Daerah;

7. Peraturan Bupati Magelang Nomor 46 Tahun 2012 tentang Pajak Bumi dan Bangunan Perdesaan dan Perkotaaan; Peraturan Bupati Magelang Nomor 49 Tahun 2012 Tentang Tata Cara Pemberian dan Pemanfaatan Insentif Pemungutan Pajak Bumi dan Bangunan Perdesaan dan Perkotaaan;

Menurut Alam, sebetulnya kewenangan penentuan BPHTB itu dapat dilakukan melalui survei lapangan, komunikasi dengan aparat desa setempat atau dengan cara dan metode yang bisa disesuaikan dengan situasi dan kondisi, berbeda halnya dengan dengan undang-undang. Ketika undang-undang itu menyatakan A tapi kenyataanya tidak dapat dilaksanakan karena begitu banyaknya permasalah di lapangan, maka pihak BPPKAD mengembangkan cara yang sekiranya menjadi terobosan dan pengembangan hukum.

Kedua, menurut Suprayitno, ${ }^{6}$ dasar pengenaan atas nilai perolehan tidak dapat diganggu gugat dimana harga riil adalah harga riil itu juga tanpa perlu adanya konfirmasi dan penyesuain atas nilai tanah tersebut dengan INT atau Zona Nilai Tanah. Mengingat pajak dapat dipaksanakan, maka lahirlah kebijakan baru dari bupati berupa

${ }^{5}$ Hasil wawancara dengan Bapak Alam Purnomo Aji, selaku Validator BPPKAD Kabupaten Magelang pada 10 Nopember 2020.

6 Hasil wawancara dengan Suprayitno, selaku Validator BPPKAD Kabupaten Magelang pada 10 Nopember 2020. 
INT. Namun, INT sekarang ini sangat rendah ketimbang harga pasar. Oleh karenanya, pihak BPPKAD menanamkan sistem dasar pengenaan pajak dalam sistem BPHTB online dipasangkan dengan nilai Zona Nilai Tanah.

Penulis mendapatkan temuan yaitu NJOP yang didalamnya memuat data tentang NJOP tidak dijadikan dasar sebagai pengenaan jumlah nilai pajak yang harus dibayarkan. Latar belakang kondisi ini terjadi diantaranya mengenai perbedaan nilai harga pasaran yang dicantumkan dengan harga yang sebenarnya disepakati. Hal ini dapat terjadi karena intervensi pihak lain karena adanya faktor taksiran nilai tanah permeter di setiap blok daerah masing-masing desa yang dilakukan oleh Dinas Pendapatan Daerah atau Kantor Pelayanan Pajak, yang mana membuat perbedaan mencantumkan harga nilai pasar ini membuat konsekuensi atau akibat hukum.

Namun fakta dilapangan berbeda, dalam pelaksanaannya pemerintah daerah dalam pelaksanaan pemungutan BPHTB tidak menggunakan INT namun karena ketiadaan peraturan yang jelas dan mengikat, pemerintah daerah justru mengikuti atau menerapkan sistem Zona Nilai Tanah (ZNT) yang merupakan tugas dan hak milik Kementerian Agraria dan Tata Ruang, Kementerian Agraria dan Tata Ruang (ATR)/Badan Pertanahan Nasional (BPN). Hal tersebut dilatar belakangi menurut salah satu7 validator BPPKAD bahwa ZNT berguna sebagai rujukan nasional atas informasi nilai tanah. ZNT Kementerian Agraria dan Tata Ruang, Kementerian Agraria dan Tata Ruang (ATR)/Badan Pertanahan Nasional (BPN) berupa Zona Geografis yang terdiri dari sekelompok objek pajak yang mempunyai nilai indikasi rata-rata sama yang dibatasi oleh batas penguasaan/kepemilikan objek pajak dalam satu wilayah administrasi Kabupaten ${ }^{8}$.

\section{Dasar Wewenang Validator BPPKAD Kabupaten Magelang Mengubah Harga Transaksi Khususnya dalam Peralihan Hak Jual Beli}

Faktor yang membuat pemerintah daerah menerapkan sistem perolehan BPHTB dengan mengaplikasikan sistem ZNT salah satunya demi menaikkan potensi kenaikan BPHTB yang dapat meningkatkan Pendapatan Asli Daerah (PAD) serta tidak kalah penting untuk meningkatkan kemandirian daerah dan pembangunan daerah dalam hal pengelolaan keuangan. Dengan tujuan seperti itu, maka diharapkan dengan penerapan sistem BPHTB dari INT menjadi ZNT, kemampuan daerah dalam hal penggalian sumber dana akan semakin baik, serta pendapatan yang bersumber dari pajak daerah terutama BPHTB proporsinya semakin besar.

Perhitungan BPHTB yang dilakukan pemerintah daerah rentan terjadi penyimpangan, sehingga dapat menyebabkan kerugian bagi masyarakat karena perhitungan BPHTB tidak sesuai dengan ketentuan yang ada. Pemerintah daerah dalam menentukan nilai BPHTB tidak sesuai dengan aturan yang berlaku, sehingga terkesan asal-asalan. Padahal, menentukan BPHTB harus berdasarkan harga transaksi. Jika nilai transaksi lebih kecil dari NJOP, BPHTB harus disesuaikan.

${ }^{7}$ Hasil wawancara dengan Bapak Suprayitno sebagai Validator BPPKAD Kabupaten Magelang pada 8 September 2020 .

8http://kab-kuburava.atrbpn.go.id/Publikasi/Berita-Kantor-Pertanahan/pemanfaatan-zona-nilai-tanaholeh-pemerintah-kabupatenkota-115819 diakses pada 28 Mei 2020 pukul 22.27 WIB. 
Kantor pajak daerah dalam menerapkan sistem perpajakan memiliki satu tujuan yang memaksa dan sudah seharusnya didasarkan pada ketentuan perundang-undangan bukan pada diskresi subyektif dari petugas validator pajak. Terlebih kantor pajak daerah wajib menerapkan sistem bahwa segala pajak yang dibayarkan harus jelas. Artinya bahwa Pendapatan Anggaran Daerah yang didapat dari pajak rakyat diperoleh bukan karena sesuatu yang salah. Suatu hal yang menjadikan momok bayangan bagi masyarakat adalah celah memainkan nilai jual beli bisa berpengaruh terhadap perolehan pajak daerah dan terhadap uang pajak yang dibayarkan oleh klien/penjual dan pembeli dan bukti bayar mereka.

Apabila keadaan seperti ini menjadi mendarah daging maka hal ini akan sangat merugikan masyarakat. Kesalahan ini tidak boleh dipelihara mengingat masyarakat kita sebagian besar juga berpenghasilan lepas harian dimana nominal uang Rp. 100.000,00 pun terkadang untuk memperolehnya harus dengan bersusah payah. Misalnya, subjek ini melakukan jual beli dan dia ditempatkan sebagai pembeli, dan misal dalam jual beli harga kesepakatan antara penjual dan pembeli tidak disepakati dan Pemerintah Daerah mewajibkan untuk naik harga, kemudian asas perpajakan wajib berdasarkan asas gaya pikul dengan melihat perekonomian setiap orang dan menerapkan Asas Efficiency dimana asas ini merupakan asas efisiensi dari asas ekonomis dimana biaya pemungutan pajak diusahakan sehemat mungkin dan jangan sampai terjadi biaya pemungutan pajak yang berlebih dari penghasilan pokok wajib pajak.

Alam, selaku validator menyatakan bahwa kewenangannya diatur sebagaimana dalam Undang-Undang Nomor 28 Tahun 2009 tentang Pajak Daerah dan Retribusi Daerah. Namun beliau tidak menjelaskan, secara implisit mengenai, kebijakan atas merubah dan memvalidasi harga sesuai standarisasi dari BBPPKAD. Penulis menelaah bahwa, dalam Pasal 87 Undang-Undang Nomor 28 Tahun 2009 tentang Pajak Daerah dan Retribusi Daerah sebagaimana telah mengatur terkait NPOP dan saat terutangnya BPHTB disesuaikan dengan objek pajaknya yaitu9:

1) Dasar pengenaan Bea Perolehan Hak atas Tanah dan Bangunan adalah Nilai Perolehan Objek Pajak.

2) Nilai Perolehan Objek Pajak sebagaimana dimaksud pada ayat (1):

a) jual beli adalah harga transaksi;

b) tukar menukar adalah nilai pasar;

c) hibah adalah nilai pasar;

d) hibah wasiat adalah nilai pasar;

e) waris adalah nilai pasar;

f) pemasukan dalam peseroan atau badan hukum adalah nilai pasar;

g) pemisahan hak yang mengakibatkan peralihan adalah nilai pasar;

h) peralihan hak karena pelaksanaan putusan hakim yang mempunyai kekuatan hukum tetap adalah nilai pasar;

i) pemberian hak baru atas tanah sebagai kelanjutan dari pelepasan hak adalah nilai pasar;

j) pemberian hak baru atas tanah di luar pelepasan hak adalah nilai pasar;

${ }^{9}$ Hasil wawancara dengan Alam Purnomo Aji, selaku Validator BPPKAD Kabupaten Magelang pada 10 Nopember 2020 
k) penggabungan usaha adalah nilai pasar;

1) peleburan usaha adalah nilai pasar;

m) pemekaran usaha adalah nilai pasar;

n) hadiah adalah nilai pasar; dan/atau

o) penunjukan pembeli dalam lelang adalah harga transaksi yang tercantum dalam risalah lelang.

Suprayitno, menyatakan bahwa sebenarnya validator itu tidak ada dan harga tanah permeter atas peralihan hak jual beli adalah mengacu pada Pasal 87 ayat (2) huruf (a) Undang-Undang Nomor 28 Tahun 2009 tentang Pajak Daerah dan Retribusi Daerah, bahwa jual beli adalah harga transaksi. Namun, pihak BPPKAD menerapkan kebijakan yang saat ini telah berjalan oleh karena pada 2013 memang benar kepengurusan atas BPHTB di Kabupaten Magelang sudah sesuai atas peraturan yang berlaku, namun disalahgunakan oleh beberapa oknum tertentu, hal paling pokok adalah merubah harga setiap transaksi untuk menghindari pajak BPHTB ${ }^{10}$.

Hipotesa penulis akan hal ini adalah BPPKAD sebenarnya tidak mempunyai kewenangan hak untuk turut serta atau ikut campur atau bahkan menentukan harga bidang tanah tertentu yang menjadi obyek peralihan hak jual beli bidang tanah tersebut. Mempelajari hal tersebut maka dapat dikatakan BPPKAD telah melakukan penyalahgunaan wewenang, dimana turut campur dalam menentukan harga peralihan hak jual beli bidang tanah yang bukanlah suatu kewenangan dari BPPKAD yang mengatur harga permeter atas tanah.

Kewenangan pemerintah daerah dalam menentukan harga jual dalam transaksi jual beli tanah dan atau bangunan yang dilakukan melalui proses validasi BPHTB tidak diatur dalam peraturan perundang-undangan. Undang-undang hanya mengatur kewenangan pemungutan BPHTB yang merupakan kewenangan pemerintah daerah, sebagaimana diatur dalam Undang-Undang No. 28 Tahun 2009 tentang Pajak Daerah dan Retribusi Daerah. Proses validasi BPHTB yang mengakibatkan perubahan harga transaksi jual beli merupakan tindakan diskresi pemerintah daerah demi meningkatkan Pendapatan Asli Daerah (PAD), tetapi tindakan yang dilakukan oleh pemerintah harus tetap mengacu pada Asas-Asas Umum Pemerintahan yang Baik (AAUPB) agar tidak terjadi penyalahgunaan wewenang yang dilakukan oleh pemerintah daerah. ${ }^{11}$

\section{Penutup}

Berdasarkan hasil dan pembahasan di atas, terdapat dua kesimpulan, pertama, landasan hukum yang digunakan oleh BPPKAD adalah Surat Keputusan Bupati Nomor 180.182/327/kep/31/2015 tentang Indeks Nilai Tanah, namun kenyataanya yang dipergunakan untuk pengenaan pajak bukanlah Surat Keputusan Bupati Nomor 180.182/327/kep/31/2015 tentang Indeks Nilai Tanah tersebut, melainkan sistem Zona

${ }^{10}$ Hasil wawancara dengan Suprayitno, selaku Validator BPPKAD Kabupaten Magelang pada 10 Nopember 2020

${ }^{11}$ Eny Kusdarini, Asas-Asas Umum Pemerintahan Yang Baik dalam Hukum Administrasi Negara, UNY Press, Yogyakarta, 2019, hlm. 8. 
Nilai Tanah yang dipergunakan oleh Kementerian ATR/BPN tanpa adanya peraturan yang mengikat untuk menggunakan sistem Zona Nilai Tanah tersebut.

Kedua, BPPKAD tidak rnemiliki kewenangan untuk turut serta atau ikut campur atau bahkan menentukan harga bidang tanah yang menjadi obyek peralihan hak jual beli oleh para pihak (antara penjual dan pembeli), kewenangannya sebatas memvalidasi SSPD-BPHTB. Undang-undang hanya mengatur kewenangan pemungutan BPHTB yang merupakan kewenangan pemerintah daerah, sebagaimana diatur dalam UndangUndang No. 28 Tahun 2009 tentang Pajak Daerah dan Retribusi Daerah. Proses validasi BPHTB yang mengakibatkan perubahan harga transaksi jual beli merupakan tindakan diskresi pemerintah daerah demi meningkatkan Pendapatan Asli Daerah (PAD). Tetapi tindakan yang dilakukan oleh pemerintah harus tetap mengacu pada Asas-Asas Umum Pemerintahan yang Baik (AAUPB) agar tidak terjadi penyalahgunaan wewenang yang dilakukan oleh pemerintah daerah.

Berdasarkan kesimpulan di atas, terdapat dua saran yakni, pertama, pihak BPPKAD seharusnya mempunyai landasan hukum yang kuat dan berpegang kepada peraturan yang berlaku ketika menjalankan tugas pokok dan fungsi sebagai Aparatur Sipil Negara dalam menjalankan tugas dan kewajibannya. Kedua, pihak BPPKAD seharusnya hanya sebatas menerima Nilai Perolehan Objek Pajak khususnya jual beli berdasarkan dari nilai riil transaksi, sesuai dengan Pasal 87 ayat (2) point (1) Undang-Undang No. 28 Tahun 2009 (PDRD) yaitu pengenaan pajak BPHTB sebatas pada harga transaksi, dan harga transaksi yang dicantumkan dalam SSPD-BPHTB tersebut tidak untuk dirubah.

\section{Daftar Pustaka}

\section{Buku}

Abdulkadir Muhammad, Hukum dan Penelitian Hukum, Citra Aditya Bakti, Bandung, 2004.

Eny Kusdarini, Asas-Asas Umum Pemerintahan Yang Baik dalam Hukum Administrasi Negara, UNY Press, Yogyakarta, 2019.

Maria S.W. Sumardjono, Pedoman Pembuatan Usulan Penelitian, PT. Gramedia Pustaka Utama, Jakarta, 1997,

Ronny Hanitijo Soemitro, Metode Penelitian Ilmu Hukum, Ghalia Indonesia, Jakarta, 1990

\section{Artikel}

Ady Supratno, "Pengaruh Perubahan Zona Nilai Tanah Dan Nilai Jual Objek Pajak Bangunan Terhadap Penerimaan Pajak Bumi Dan Bangunan Perdesaan Dan Perkotaan Kabupaten Sambas", Artikel Ilmiah, Program Studi Magister Ilmu Ekonomi Fakultas Ekonomi Dan Bisnis Universitas Tanjungpura, 2018.

\section{Peraturan Perundang-Undangan}

Undang-Undang No. 28 Tahun 2009 tentang Pajak Daerah dan Retribusi Daerah.

\section{Keputusan}

Surat Keputusan Bupati Nomor 180.182/327/kep/31/2015 tentang INT di Kabupaten Magelang. 


\section{Surat Edaran}

Surat Edaran Direktur Jenderal Pajak Nomor SE - 33/PJ/2019 tentang Petunjuk Pelaksanaan Peraturan Direktur Jenderal Pajak Nomor Per-08/PJ/2019 tentang Tata Cara Pemberian, Penyesuaian dan Penghapusan Nomor Objek Pajak-Pajak Bumi dan Bangunan. Pada Point E Bagian Materi Nomor 2.

\section{Wawancara}

Hasil wawancara dengan Alam Purnomo Aji selaku Validator BPPKAD Kabupaten Magelang pada 10 Nopember 2020.

Hasil wawancara dengan Suprayitno selaku Validator BPPKAD Kabupaten Magelang pada 10 Nopember 2020. 